\title{
The Leading Factors behind the Improved Efficiency and Growth of Banking Sector in Jordan
}

Sameer A. A. AlZoughool ${ }^{1 *}$, Proff Ahmed Azrin Adnan², Dia Khalaf Ahmed AlQatawneh ${ }^{3}$, Tamer Hussain Ahmad AlQudah $^{4}$

1,3,4 Phd Students, UniSZA University, Kuala Terengganu, Malaysia

${ }^{2}$ Lectrure, UniSZA University, Kuala Terengganu, Malaysia

DOI: $10.36347 /$ sjebm.2020.v07i01.005

| Received: 02.12.2019 | Accepted: 14.12.2019 | Published: 29.01.2020

*Corresponding author: Sameer A. A. AlZoughool

Abstract

Review Article

This article provides an analysis on the banking sector of Jordan. It specifically focuses on the leading factors that have played significant part in improving the efficiency and growth of Jordanian banks. The Central Bank of Jordan policies and regulations were studied and it is found that banks in the country strictly follow these policies to avoid any negative consequences. It is not easy for new entrants (both domestic and foreign banks) to enter the banking industry of the country. They need to go through startup procedures to enter in the market. It restrict any potential new bank that may have negative impact on the overall banking industry. The advancement in technology has allowed Jordanian banks to improve services as provided to the customers. Hence, leading positively to the overall banking industry. General Agreement on Trade is another important factor that improved the banking sector of Jordan. Human resource, high competition and supply chain integration are other important variables studied in this article for analyzing the performance of Jordanian banks.

Keywords: Factors, Banking Sector, Jordanian banks.

Copyright @ 2020: This is an open-access article distributed under the terms of the Creative Commons Attribution license which permits unrestricted use, distribution, and reproduction in any medium for non-commercial use (NonCommercial, or CC-BY-NC) provided the original author and source are credited.

\section{INTRODUCTION}

The financial sector of Jordan represents approximately $20 \%$ of the total Gross Domestic Product of the country [1]. The banking sector dominates the overall financial sector of the country which is highly profitable, capitalized and is expected to play key role in the development of private sector in Jordan. The banks operating in Jordan are regulated by the Central Bank of Jordan's policies. Jordan's Central bank maintains banking and monetary stability by keeping a control on rates of inflation and ensuring that the rates of foreign exchange are stabilized. It becomes important to study the key factors that have contributed to the increased efficiency and growth of the Jordan's banking sector [2].

This study has identified and discussed those factors that played vital role in overall banking sector of the country. The GATS agreement known as the General Agreement on Trade in Services is considered to be an important factor in overall success of Jordanian banking sector. Therefore, this research paper studies the agreement of GATS signed by the government of Jordan in 2000 for assessing how this agreement assisted to encourage openness and competitiveness of the banking sector in Jordan [3]. The second important success factor of high efficiency in the banking sector of Jordan is the use of technology. The banks of Jordan have taken into use the new products and services in the retail banking by adopting advanced technology. Ebanking in Jordan is also increasing significantly as most customers prefer to transact online without having the need to physically go to the bank. The regulatory system of the country has also played significant role in the overall success of Jordanian banking sector. Hence, regulatory reforms that have increased competition in the banking sector of Jordan are studied and explained in this research.

\section{Banking Sector of Jordan}

The banking sector as the part of overall financial sector plays an important part in the overall performance of an economy. A central role is played by banks in the process of money creation and in the system of payment. Furthermore, one of the important factors in the financing of growth and investment in bank credit. Therefore, a special interest lies in maintaining the effectiveness of banking system for the regulators. Jordan's banking sector has shown positive 
growth and increase efficiency in past few years [4]. All the financial transactions in the country are mostly intermediated through banks. The sector of banking in Jordan is completed owned privately, profitable and well developed. A total of 25 banks are operating in the country. It includes eight branches of international banks and two Islamic Banks. The operations of banks are carried out through more than 500 branches throughout the country. The attractive economic conditions of the country in 2007 had positive impact over the sector of banking that have grown continuously and positing more than $100 \%$ growth rates in almost every aggregate. The credit facilities provided by banks in Jordan are seen as strong factor contributing to the growth of activities of the banks. These facilities take into account large companies with substantial liquidity as well as individuals with personal loans [5].

\section{Role of CBJ in the Growth of Banks in Jordan}

The Central Bank of Jordan is regulating the overall banking sector of the country which was developed in 1964. Despite being funded by the government, it remains as an independent institution. There are many changes in the rules and regulations of country's banking system to ensure that they are competitive and possess absolute high international standards [6]. CBJ has de-regulated the credit's allocation and interest rates and introduced modern supervision and regulation. Strict controls by the CBJ have ensured that the banks are consistent with the norms of international banks. Foreign currency, bank payments, transactions, government securities, risk based provision, internal loans, commercial papers, liquidity management, deposit insurance, and payments made by credit/debit cards are the few areas where CBJ keeps a regular eye on the Jordanian banks. The entrants in the banking sector of Jordan are required to fulfill some important conditions to operate in the country including registering as public limited companies, presenting complete business plan, paying license fee and maintaining minimum of 40 million JD capital. The same policies apply for foreign banks with the exception of minimum 20JD million for capital. This ensures that every entrant in the banking sector of the country is effective and contributes positively to the overall sector. Every bank in Jordan needs to publish financial statements both semiannually and annually. These banks are also subject to be inspected both onsite and off-site. These policies have encouraged the banks in the country to be highly transparent and effective. The management of the Jordanian banks is aware of the fact that huge consequences can be faced if they fail to obey the rules and regulations of CBJ [7].

\section{GATS Agreement as the Contributor of Growth \& Efficiency in Jordan}

The GAT agreement can be seen as the restrictiveness measure that has controlled the banking sector of Jordan. GATS have removed the restrictions of capital account for facilitating cross border consumption and supplies abroad. Hence, the facilitation of capital's international flow have ensured that investments flow globally to the enterprises where they are more productive in terms of risk and gain in the regime of new world trading. Every bank in Jordan is allowed to take part in the issues related to securities and management of asset. Banks are also able to provide recommendations and other financial services internationally. As the banks in Jordan are required to for the international standards, they are very conscious about the quality of services being provided to both individual customers and corporations. As the banks are following the regulations of GATS agreement, they are able to maintain absolute best standards. This has enabled customers of banking sector in Jordan to enjoy international level services [8].

\section{Adaption of Advanced Technology by Jordanian Banks}

Every bank in Jordan's banking industry is providing advanced technology facilities to the customers. The use of advanced technology has allowed these banks to ensure the safety and security of the client's financials and personal information. Banking is a very sensitive sector. The banks need to ensure that the money deposited by customers is held secure. When banks provide online services to the customers, the first and foremost important aspect is the security. A lack of security can create tremendous problems for both bank and the customers. Therefore, the banks in Jordan have adopted most secure online measures to ensure that Ebanking is provided without any risk of online theft or cybercrime [9].

The customers of banking sector in Jordan are provided with online facilities where almost every transaction can be made online without having the need to physically go to the bank and perform transaction. There are only few services that require customers to physically go to the branch. It gives an ease to customers and encourage them to use more of banking services. In a research conducted by Ajlouni et al. [6], the importance of technology in the banking sector was studied and it was suggested that technology has played a significant part in improving the efficiency of Jordanian banks as compared to the banking sector of neighbor countries. The customers of Jordan banking sector are able to receive their statements on email to check their transactions. They can request check books and card online and receive at their door step without requiring to go to the bank. It is easier for the customers to make payments online including funds transfer to others, online payment for utility bills, buy airline tickets and others. The advancement in technology has allowed banks in Jordan to improve in terms of effectiveness and efficiency. The Enterprise Resource Planning system used by banks in Jordan has also been significant in improving the performance of the banks. Al Nimer [9] explained the implementation of ERP system in Jordan banks as being success factor on 
financial performance. The study suggested that ERP implementation does not bring significant increase in Return on Investment; however, it does improve overall performance of banks. The increased investment on information technology and borderless business environment has improved the performance of banks in Jordan.

\section{Other Important Factors Impacting the Performance of Banks in Jordan}

Measuring performance of banks in terms of growth and efficiency is not an easy task. There are wide range of factors that have contributed to success of Jordan banking sector. Due to limitation of time, it was not possible to study all of these factors. However, few of the other factors that have improve efficiency level of banks in Jordan include supply chain integration, human resource management and high level of competition between banks. Pakurár et al. [10] studied the role of supply chain integration in impacting the performance of banks in Jordan. It was found that the supply chain plays a vital role in improving the performance of the banks in the country. Internal integration and customer integration are two parts of supply chain that have shown positive impact on the internal processes, finance, customer satisfaction and capacity of organization for Jordanian banks. It means that a significant improvement in the supply chain can leave to significant increase in effectiveness and efficiency of the banks. The human resource in terms of management and leadership in banking industry of Jordan has played important part in the growth and efficiency of overall industry. The employees and managers working in banks in Jordan are highly educated and trained. The leadership of the banks has ensured that they are able to follow all the rules and regulations placed by the regulating bodies. The completion within the banking industry has encouraged the banks in the country to come up with different promotions for attracting and retaining customers. These banks try to maintain the best level of quality to compete effectively in the industry [11].

\section{CONCLUSION}

Banking industry is important part of every given economy. In Jordan, banking industry contributes to a large portion of overall Gross Domestic Product of the country. The whole financial sector of Jordan is dominated by the banking sector. The study on the overall banking sector of Jordan has shown that the country's banks have improved and achieved tremendous growth and high efficiency. There are many factors that have contributed to the positive performance of banks in Jordan. However, the most significant factors have proven to be the regulations of CBJ, GATS Agreement restrictions, advanced technology, human resource management, and high competition and supply chain integration. Therefore, it can be concluded that further efforts to bring improvements in these areas can help banks in Jordan to perform more effectively and efficiently. This research has also provided a direction for future researchers and scholars to study these variables in other countries. It is recommended that the regulatory bodies of banking industry can adapt the policies of the CBJ to achieve growth and higher efficiency.

\section{REFERENCES}

1. Acosta PA, Baerg NR, Mandelman FS. Financial development, remittances, and real exchange rate appreciation. Economic Review. 2009;94.

2. AbuShanab E, Pearson JM. Internet banking in Jordan: The unified theory of acceptance and use of technology (UTAUT) perspective. Journal of Systems and information Technology. 2007 Aug 22;9(1):78-97.

3. Al-Shakhanbeh N. The Impact of the General Agreement on Trade in services.(GATS) on the Banking sector in Jordan. Master Degree Thesis, the University of Jordan. 2005 May.

4. Al-Zoubi MR. The Impact of Intellectual Capital on SWOT Analysis among Jordanian Banking Industry" Empirical Study. International Journal of Business and Social Science. 2013 Feb 1;4(2):12337.

5. Cornford A. Statistics for International Trade in Banking Services: Requirements, Availability and Prospects. United Nations Conference on Trade and Development; 2009.

6. Hmedat MW, Hmedat W. The relative efficiency of Jordanian banks and its determinants using data envelopment analysis. Journal of Applied Finance and Banking. 2011 Jul 1;1(3):33.

7. Al-dalahmeh M, Khalaf R, Obeidat B. The effect of employee engagement on organizational performance via the mediating role of job satisfaction: The case of IT employees in Jordanian banking sector. Modern Applied Science. 2018;12(6):17-43.

8. Fischer J, Khan I, Khemani T, Mak D, Najmi R. Jordan tourism cluster. Report for Microeconomics of Competitiveness. 2009 May 8;8.

9. Al-Nimer M, Omush A, Almasarwah A. ERP implementation in banks: success factors \& impact on financial performance. Banks and Bank Systems. 2017;12(4):17.

10. Pakurár M, Haddad H, Popp J, Khan T, Oláh J. Supply chain integration, organizational performance and balanced scorecard: An empirical study of the banking sector in Jordan. Journal of International Studies Vol. 2019;12(2).

11. Mattoo A. Developing countries in the new round of GATS negotiations: towards a pro-active role. The World Economy. 2000 Apr 1;23(4):471-89. 